\title{
The changing understanding of the Eucharist among the Kikuyu communicants of the Thika Diocese in the Anglican Church of Kenya
}

\author{
Kiarie, George \\ University of South Africa \\ kiarie_george@yahoo.com \\ Joshua, Stephen Muoki ${ }^{1}$ \\ University of South Africa \\ s.muoki@pwaniuniversity.ac.ke
}

\begin{abstract}
This article is set out to explicate the changing understanding of the Eucharist among the Kikuyu communicants in the diocese of Thika since its introduction by the Anglican missionaries. The concept of Athomi, literally rendered as "leaners", ascribed communicants the attributes of continuing Christian learners full of spiritual expectation in the holy communion sacrament. These days however, that "unique thing" is absent as the service is invaded by "the wrong people" with "mud". The article is informed by qualitative data collected among the members and clerics of Thika Diocese in the Anglican Church of Kenya (ACK). It argues that the changing perception of the Eucharist by communicants of Thika diocese is largely influenced by Kikuyu's incarnation of the meal elements, the manner in which the meal is administered, the preparation of the communicants and the teachings on the subject by clerics. Informed by the incarnation theory, the article further argues that there is a need for an ideological shift in the diocese so that the Eucharist is not merely perceived as affecting the social relationships and individual identity but more so the spiritual wellbeing as a means of conveying God's grace.
\end{abstract}

Key words

Inculturation; Anglican tradition; missionary; Kenya; East Africa; Eucharist; Holy Communion; elements

1 George Kiarie is an ordained Anglican priest in Kenya. He is a parish priest in the diocese of Thika and serves as an Adjunct Lecturer at St. Paul University Limuru Kenya. 


\section{Introduction}

The administration of sacraments is central to Anglican tradition. Indeed, for the Anglican Church in Kenya (ACK), Eucharist and baptism are the central sacramental rites in the life of her Christians. These two sacraments became identical to the English missionaries Anglican Church establishment in the East African Coast during the 1880s. The Eucharist came as a totally new phenomenon to the local people. Jesse Mugambi argues that the use of bread and wine in the Eucharist meal came as a new cultural and religious experience to the African people such that some Christians would taste bread and wine for the first time at the Holy Communion. ${ }^{2}$ However, this has gradually changed and the late bishop Henry Okullu argued that in many African homes bread has almost become a staple diet and wine is no longer a strange thing met only at Communion. On the contrary, it is a common commodity consumed by Africans at parties and in their homes. ${ }^{3}$ To this end, the Eucharist is no longer a strange meal to many Anglicans in Kenya today because the elements used in this meal are accessible to many Kenyans if not all. The question that largely informs this article is how, if at all, this new dispensation informed a deeper understanding and practice of this sacramental meal in the Kenyan context. The article argues that on the contrary, this deeper understanding and practice of the sacramental meal has over the years become a catalyst to make many Anglican adherents commit travesty in this holy meal?

The article relied on data that was generated using both empirical and non-empirical methods. The data was collected from twenty-five parishes [out of sixty parishes in the diocese] where the participants comprised of both the clergy and laity in the ACK diocese of Thika. Semi-structured interviews, focus group discussions and questionnaires were used in data collection. Sixty-seven participants were engaged in this study and were purposively sampled. The researchers selected sixty-seven participants within the diocese of Thika that were well informed and with deeper

2 Jesse Mugambi, African Heritage and Contemporary Christianity, (Nairobi: Longman Kenya Limited, 1989), 104-105.

3 Henry Okullu, Church and Politics in East Africa, (Nairobi: Uzima Press, 1974), 56 - 57. 
knowledge of the subject of Eucharist. ${ }^{4}$ The collected data was analysed qualitatively. ${ }^{5}$

\section{Christianity as faith seeking understanding through culture}

Notably, Christianity is a unique faith that is always "pregnant" and ready to be "born again" when it encounters a new context. As an expectant faith, it dialogues with the new context where it affirms some cultural practices of the people and also critique the cultural practices that are repugnant to the gospel of Christ in that context. As such, this study employs incarnation theory by Laurenti Magesa as its theoretical perspective. In this theory, Magesa argues that the Christian faith has to assume the people's flesh if it has to communicate to the people and touch their consciousness deeply. ${ }^{6}$ He proposes that Christianity as faith seeking understanding through culture, is obliged to become part of a particular people, and immersed in a particular language and ways of doing things if it will truly be born again in that given context. ${ }^{7}$ When this is done he perceived that the Christian message enters the very blood of the people and make the Christian faith respond to their aspiration and anxieties as well as make them recover their identity and dignity. ${ }^{8}$

It is in this regard that we are using Magesa's theory to evaluate the extent to which this Eucharist has been incarnated in the ecclesiastical context of Thika when it was introduced by the English missionaries. This theory also helps to examine the message conveyed by this meal to the diocesan Christians. Furthermore, it will attempt to answer whether this Eucharist is intended for spiritual nourishment or social identity or both.

4 John W Creswell and Vicki L Plano, Clark, Designing and Conducting Mixed Methods Research, (Thousand Oaks: SAGE Publications, Inc., 2007), 112.

5 Richard E Boyatzis, Transforming Qualitative Information: Thematic Analysis and Code Development, (Thousand Oaks, CA: SAGE Publications, Inc., 1998), vi.

6 Laurenti Magesa, Anatomy of Inculturation: Transforming the Church in Africa, (Maryknoll: Orbis Books, 2004), 137.

7 Magesa, Anatomy of Inculturation, 137.

8 Magesa, Anatomy of Inculturation, 174. 


\section{Historical development of the Eucharist in the ACK}

The Eucharist bears its origin in the Jewish context, where the bread and wine formed their source of daily nourishment whenever the Jewish Community had a meal. Besides, this meal been the source of their nourishment, Eugene Uzukwu argues that it also formed part of their religious life because during their religious rites this meal became the food offered for thanksgiving and sacrifice. ${ }^{9}$ However, with time Jesus reinterpreted the religious significance of this meal and gave it a broader understanding to the wider global communities. ${ }^{10}$ This meant that this meal was viewed as the body and the blood of Christ that was broken and shed respectively for the atonement of humankind $\sin .{ }^{11}$ As such, this Eucharist became the official ecclesiastical meal used by Jesus' apostles and the Early Church whenever the Community of believers met to break the bread on the Lord's Day. ${ }^{12}$

While all along the bread was been used in the Eucharist, there was introduction of wafers according to Janny De Moor in the $4^{\text {th }}$ Century that saw this bread type been adopted for Ecclesiastical use by stamping it with the Greek letters "xp" for Christ. ${ }^{13}$ With time, the Christian Community of believers became elaborate and this saw the community divided into two blocks namely the Eastern and Western Christendom. It was prompted by doctrinal issues and supremacy battle between Constantinople and Rome. In this case, the use of Eucharistic elements and particularly the bread or wafers whether leavened or unleavened in the Eucharist became a contentious issue in $8^{\text {th }}$ century that brought a tag of war between the East and West. ${ }^{14}$ Though this contentious debate may be ascribed to the East and West block of Christianity, Dyson Hague notes that it also emerged later in

9 Eugene Uzukwu, "Foods and Drink in Africa and the Christian Eucharist", African Ecclesial Review, (22/6, 1980), 376.

10 John W Howe and Sam C Pascoe, Our Anglican Heritage: Can an Ancient Church be a Church. (Eugene OR: Wipf and Stock Publishers, 2010), 81.

11 See Anglican Church of Kenya. Our Modern Service (Nairobi: Uzima Press, 2002).

12 Paul, Dearmer. The Parson's Handbook Ninth edition (London: Humphrey Milford, 1917), 144.

13 Janny De, Moor. "Wafers and its Roots". In Look and Feel: Studies in Texture, Appearance and Incidental Characteristics of Food Proceeding of the Oxford Symposium on Food and Cookery, edited by Harlan Walker, (Oxford: Prospect Books., 1994), 123.

14 Tim, Dowley (ed.). The History of Christianity (Oxford: Lion Publishing Plc., 1990), 265. 
the Western block of Christianity particularly in England when it stopped paying loyalty to Rome by cutting off ties. ${ }^{15}$

When the Church of England was formed, it continued to use unleavened bread rather than wafers in the Eucharist. ${ }^{16}$ However, this attracted a lot of criticism and divisions in England at its formative years between those who opts wafers rather than bread. ${ }^{17}$ It is only during the reign of Queen Elizabeth as the Head of State and the Head of the Church of England, that she arrested the escalating rivalry. She brought reforms in the Church of England and parts of these reforms touched the liturgical life of the Church. ${ }^{18}$ Sacraments been the borne of contentions in the British Aisle, the Parliament through an act recommended the use of wafers rather than bread in the Church of England. The reason been it is by "far more convenient than common bread and involves smaller risks of irrelevance."19 Certainly, wafers became the official type of bread (with wine) for use in the Church of England and in the other mission Churches that it established abroad. Unfortunately, wafers disappeared due to breaking of the Second World War and only to be reintroduced later in the ninth century according to Ruth Meyer. ${ }^{20}$ In this note, when the English missionaries introduced this Eucharist in Kenya, the wafers and wine formed were integral part of the elements.

\section{Anglican Church of Kenya's Diocese of Thika and the Sacrament of the Eucharist}

The ACK considers the Holy Communion or the Lord's Supper as an ecclesiastical meal celebrated in the local ecclesiastical contexts and as part of fulfilling Christ command to the Church to be doing "this in remembrance of me." Consequently, the meal is celebrated in the ACK diocese of Thika within the local context of the Kikuyu people who are Bantu ethno-linguistic people believed to have come from West Africa

15 See Dyson, Hague. Through the Prayer Book (London: Longmans Green \& Co, 1932).

16 Jean-Jacques, Von Allmen. The Lord's Supper (London: Lutherworth Press, 1969), 42.

17 See Hague, Through the Prayer Book, 276.

18 Dearmer, The Parson's Handbook, 144.

19 Dearmer, The Parson's Handbook, 314.

20 Ruth A, Meyer. “The Common Cup and Common Loaf”. In Revising the Eucharist, edited by David R. Holeton, (Nottingham: Grove Books Ltd, 1994), 46. 
border between Nigeria and Cameroon about two thousand years ago. ${ }^{21}$ This means that the ACK diocese of Thika is a Church influenced and shaped by Kikuyu ethnic group worldview while on the other hand, as a member of the ACK, the diocese has the mission and vision to "equip God's people to transform her society with the Gospel as it envisions a growing and caring church boldly proclaiming Christ." 22 To achieve this, the Eucharist plays a pivotal role in realization of the ACK mission and vision.

As an ecclesiastical meal instituted by Christ, bread and wine form the ingredients that are the visible signs of invisible realities. As such, this meal points beyond itself as it brings the transcendent within the range of human understanding. ${ }^{23}$ And it invites believers to note that:

Our saviour Christ called the material bread which he broke, his body, and the wine, which was the fruit of the vine, his blood. And yet he spoke not this to the intent that men should think that the material bread is his very body, or that his very body is material bread; neither that wine made of grapes. But to signify unto us, as St. Paul saith, that the cup is a communion of Christ blood that was shed for us, and the bread is a communion of his flesh that was crucified for us. ${ }^{24}$

Indeed, this insinuates that this meal represents the body and blood of Christ that nourishes believers both physically and spiritually. For through celebration of this meal in the church, the Anglican reformer Thomas Cranmer observed as every human being is carnally fed and nourished in his or her body by meat and drink, even so is every good Christian spiritually fed and nourished in his or her soul by the flesh and blood of our saviour Christ. ${ }^{25}$ It then becomes certain that this ecclesiastical meal in a local ecclesiastical context provides spiritual strength to believers in their Christian faith.

21 Mary M. Wanyoike, Wangu wa Makeri, (Nairobi: East African Educational Publishers Ltd, 2002), 1.

22 Anglican Church of Kenya, Church Diary and Lectionary, (Nairobi: Uzima Press, 2015).

23 John Macquarrie, A Guide to the Sacraments, (London: SCM Press, 1997), 31.

24 C.S Meyer, Cranmer's Selected Writings, (London: SPCK, 1961), 31.

25 Thomas Cranmer, Cranmer on the Lord's Supper: A Defence of the True and Catholic Doctrine of Sacrament, (Kent: Focused Christian Ministries and Harrison Trust, 1987), 16. 
Besides spiritual nourishment and strength, this meal saturates believer's life with God's grace because the wafers and wine point beyond them and convey the grace of God. Welchman states that Christ not only did he became badge of tokens to Christian but rather certain sure witnesses and effectual signs of grace in God's good will toward humanity. ${ }^{26}$ Through this meal, God's redemptive work is visible in the life of humanity such that it not only quickens but also strengthens and confirms believer's faith in God. This implies that the conveyed grace is God's gift to humanity that strengthens and makes humanity inclined toward God. And as such this grace of God according to Stephen Neil should be exercised for the good of the church and not for self-edification. ${ }^{27}$

Consequently, this meal unites believer both vertically and horizontally. For in the gesture of sharing one bread and one cup becomes a sign of their unity and affirm their oneness with one another because despite being many they are one body for they all share one bread. ${ }^{28}$ While believers are united with one another, they also encounter God in this Eucharist since the self- emptying God (Kenosis) and self - surrendering humanity meet one another. As GWH Lampe argues, in this encounter between God and believers in the Lord's Table culminates to "individual union with God, and both God and man [sic], in whom the self- giving of God and the selfsurrender of man [sic] meet." ${ }^{29}$ Furthermore, it is worth noting that this encounter with self-emptying God not only unites believers with God but also guarantees eternal life to believers. Cranmer was persuaded that "touching this meat and drink of the body and blood of Christ, it is true, both he eateth and drinketh them, hath everlasting life, and also he that eateth and drinketh them not, hath not everlasting life." 30

26 Welchman, The Thirty-Nine Articles of the Church of England, (London: Oxford Theatre, MDCCLVII), 61.

27 Stephen Neil, "Holy Communion in the Anglican Church", in Martin Hugh. ed., The Holy Communion, (London: SCM Press Ltd, 1947), 62.

28 Anglican Church of Kenya, Our Modern Service, (Nairobi: Uzima Press, 2002), 82.

29 GWH Lampe, Doctrine in the Church of England, (London: SPCK, 1982), 165.

30 Thomas Cranmer, Cranmer on the Lord's Supper, 4. 


\section{Eucharistic theology in the Anglican Church of Kenya (ACK)}

Scholars such as Christopher Cocksworth (1991) and Brian Douglas (2012) maintain that the nature of Eucharistic theology in the wider Anglican Communion is multiform. ${ }^{31}$ This means that there are diverse natures of Eucharistic theology depending from one Province to the other in the Anglican Communion. A good example is the ACK where her nature of Eucharistic theology is unique in relation to other Provinces as it is highly influenced by the evangelical teaching bequeathed by CMS missionaries when this Church was introduced in the nineteenth century. Her nature of Eucharistic theology is as analysed here below.

\section{Thanksgiving}

Thanksgiving is one of the central Eucharistic theological understandings in the ACK where in this meal the Christians give thanks to God because of his provision of physical and spiritual food to them in the form of wafers and wine for spiritual nourishment. This is reflected in her Eucharistic liturgy that asserts that through your goodness, Lord, we have this bread and wine to offer, the fruits of the earth and the work of human hands; they will become our spiritual food. ${ }^{32}$ As they see this sacrament portraying God as the author and provider. However, the use of foreign and imported food products in the ecclesiastical context of Kenya in the form of wafers and branded "altar wine" raises questions: how can Kenyan Christians rejoice and claim wafers and wine are the fruits of their earth and work of their hands while they are imported food products from Europe? In the Eucharist, the European food products used rather than locally produced food products. Do these imported food products form part of thanksgiving or alienate Kenyans as recipients?

On one hand, the use of foreign symbols in this Eucharist alienates the Kenyan Christians while on the other hand the meal invokes thanksgiving to them due to the honourable invitation they receive to dine with Christ

31 See Christopher John Cocksworth. "Eucharistic Theology". In The Identity of Anglican Worship, edited by Kenneth E. Stevenson and Bryan D. Spinks, 49-68. (London: Mowbray, 1991) and Brian Douglas, A Companion to Anglican Eucharistic Theology Vol. 2: The 20th Century to the Present, (Leiden: Brill, 2012).

32 Anglican Church in Kenya, 80. 
in spite of their unworthiness. Christ welcomes them to feed at his Table even if they do not deserve such privilege the way Justin Martyr observed God invites humanity in this holy meal though unworthy to participate in it. It becomes an opportunity for the Kenyan Christians to thanks God for having them deemed worthy of these gifts. This means that the hospitable God welcomes all in the household of God to dine with Him. Although the "Open Table or Communion" is a contentious new trend in the Anglican Communion as far as this Eucharist is concerned, the questions remains in the ACK why exclude polygamous, men who have not solemnised their unions in the Church or the single mothers who desire to join others in remembering the atonement of their sin in this life giving meal?

\section{Sacrifice}

Sacrifice is the other Eucharistic theology that the ACK subscribes to. The ACK as an evangelical Church emphasizes on this Eucharist as spiritual sacrifice being offered whenever celebrated, the same way the Early Church Fathers, Cyprian and Cyril of Jerusalem described it as a spiritual sacrifice, a bloodless service, a propitiatory sacrifice, offered by the way of intercession for all who are in need of help. ${ }^{33}$ It becomes a thanksgiving sacrifice to the ACK Christians because it reminds them of Christ's atonement of their sins. Where in this meal it remains the perfect sacrifice offered once and for all with infinite intrinsic value of cleansing believers to be outstanding before God. ${ }^{34}$ As a sacrificial meal it comes to the ACK Christians with privileges on one side, while on the other hand with responsibilities since through the sacrificial death of Christ celebrated in this meal it brings the message of salvation to Christians after being reconciled to God. It also calls upon the Christians to surrender their lives to God wholly, a thing that distinguishes them with other non-Christians. Cranmer expressed this dialectical function of this Eucharistic theology succinctly that the first kind of sacrifice Christ offered to God for us; and the second kind we offer ourselves to God by Christ. And by the first kind of sacrifice, Christ

33 JF Bethune-Baker, An Introduction to the Early History of Christian Doctrine: To the Time of the

Council of Chalcedon. (London: Methuen \& Co., 1903), 410.

34 Anglican Church of Kenya, 81. 
also offered us unto his Father; and by the second we offer ourselves and all we have, unto him and his Father. ${ }^{35}$

\section{Memorial}

The bishop emeritus Gideon Githiga in his works Effective Church Leadership (2009), discloses another nature of Eucharistic theology in the ACK. He viewed the Eucharist as a memorial supper. ${ }^{36}$ This nature of Eucharistic theology is identical to the African concept of libation that entails remembering and communing with the ancestors at every meal. It is with this African understanding that this ecclesiastical meal got contextual meaning as memorial meal. Though this understanding of the Eucharist as a memorial was borrowed from Jesus' command to his disciples when he instituted this sacrament ( $\mathrm{Lk} 22: 14-20)$. In the way the disciples were charged by Christ to be celebrating this Eucharist quite often as the Gospels assert "... Do this in remembrance of me." (Lk 22:19), it is the same way the ACK understand her mission identity. Nevertheless, this memorial meal is celebrated occasionally in the ACK, and it remains a token to remember Christ until the day he will return in glory. ${ }^{37}$ As token of remembrance to believers in the ACK, the church holds that it becomes a memorial of Christ's incarnation and his suffering and death, for in it christians remember Christ becoming like us [incarnation] with a purpose of atoning our sin. It becomes good opportunity to the ACK Christians to remember Christ's meritorious death on the cross that calls upon them to proclaim the mystery of their salvation. In this mystery, Howard Mashall see believers invited to participate in it where they are transformed and become the preachers until Christ comes again..$^{38}$ As they are sent to the world to love and serve the Lord, the same way Christ was sent by the Father into the world. ${ }^{39}$

35 Michael Moreton. “The Language of Christian Mystery of Redemption”. In Signs of Faith, Hope and Love: The Christian Sacraments Today, edited by John Greenhalgh and Elizabeth Russell, 45-56. (London: St Mary's Bourne Street, 1987), 48.

36 Gideon Githiga, Effective Church Leadership, (Nairobi: Uzima Press, 2009), 74.

37 See John S Mbiti, New Testament Eschatology in an African Background: A Story of the Encounter between New Testament Theology and African Tradition Concepts, (London: SPCK, 1971).

38 Howard I. Mashall, Last Supper and Lord's Supper, (Exeter: The Paternoster Press, 1980), 113.

39 Anglican Church of Kenya, 81. 


\section{The grace of God}

The grace of God is the other Eucharistic theology conspicuous in the ACK where the Church teaches that wafers and wine as symbols used in the Eucharist point beyond them and convey the grace of God. The efficacious grace of God in this Eucharist is received through participating in eating and drinking the body and blood of Christ, that not only quickens but also strengthens and confirms the Christians faith in God. ${ }^{40}$ Interestingly, the ACK continues to teach that this grace works in a mysterious way. As neither the sinners receive it nor the administration of the wafers and wine by morally contemptible priest, hinder its efficacy to convey the grace of God in the life of those who receive them by faith. For the sacraments are efficacious ex opere operato and not ex opera operantis. ${ }^{41}$ This means on account of the work which is done. Here means the efficacy of the sacraments is understood to be dependent upon the grace of Christ, which the sacrament represent and convey. ${ }^{42}$ Consequently, the Article XXVI of Thirty Nine of Faith ascribed to the Anglican tradition that ACK also shares clarifies this doctrine of ex opere operato further as follows:

Although in the visible Church the evil be ever mingled with the good, and sometime the evil has chief authority in the ministration of the word and sacraments; yet forasmuch as they do not the same in their name, but in hearing the word of God, and in receiving of the sacraments. Neither is the effect of Christ's ordinance taken away by their wickedness, nor the grace of God's gifts diminished from such, as by faith and rightly do receive sacraments ministered unto them, which be effectual, because Christ's institution and promise, although they may be ministered by evil men. ${ }^{43}$

However, while the doctrine of ex opere operato is the official theological standing of the ACK, in practice what is observable is the other way round. The doctrine of ex opere operantis seems to be practiced in the life of the

40 Anglican Church of Kenya, 55.

41 This was the teaching of the Donatists who insisted that the validity of the sacrament depended upon the moral standing of the priest administering the sacraments.

42 Alister E McGrath., Christian Theology: An Introduction, (Oxford: Blackwell, 2001), 515.

43 Welchman, The Thirty-Nine Articles of the Church of England, (London: Oxford Theatre, MDCCLVII), $61-62$. 
ACK for we have witnessed some communicants refrain to partake in the Eucharist if celebrated by a contemptible priest or to share together with unrepentant communicants. This is in spite of the ACK teaching that those who receive the Eucharist symbols unworthily only receive the material bread and wine referred as the sacramentum and those who receive faithfully the Eucharistic symbols receive the body and blood of Christ referred as res. ${ }^{44}$

\section{The presence of Christ}

The presence of Christ in the Eucharist is the final theology held by the ACK. The Eucharist being the apex of the ACK worship there is no doubt that God's presence is inevitable. This is crystal clear in the morning prayer liturgy in the prayer of Saint Chrysostom that alludes that where two or three are gathered in his name, God will be in their midst. ${ }^{45}$ Therefore, in the Eucharist the presence of God is not only experienced but it is also invoked during the celebration and consecration of the Eucharistic symbols that represent the invisible and divine presence of the body and blood of Christ. ${ }^{46}$ When the partakers in this holy meal are invited to dine at the Lord's Table, they encounter Christ spiritually through the act of eating and drinking his body and blood.

While Cranmer being influenced by St. Augustine on justification by faith in his theology of reception by faith, he argued that "doubt not but our Lord Jesus Christ is everywhere as God and as a dweller he is in man that is the temple of God and he is in a certain place in heaven, because of the measure of a very body. ${ }^{47}$ This Eucharistic theology got a spiritual interpretation in the ACK where Christ is perceived to be spiritually present in the Eucharist. Therefore, the ACK as an evangelical Church does not hold to the doctrine of transubstantiation like the Roman Catholic

44 See William R Crocket, Eucharist: Symbol of Transformation, (New York: Pueblo Publishing Company, 1989), 276.

45 Anglican Church of Kenya, 15.

46 Githiga, Effective Church, 75.

47 John Edmund Cox ed., Works of Archbishop Cranmer on the Lord's Supper, (Cambridge: Cambridge the University Press, MDCCCXLIV), 94. 
tradition that place emphasis on real presence of Christ in this meal ${ }^{48}$ or to consubstantiation like the Lutherans where Christ is present in and under the consecrated symbols. ${ }^{49}$

\section{The changing understanding of the Eucharist in the ACK Diocese of Thika}

As we argued above it is worth noting that Eucharist is one of the central sacramental rite in the life of Anglican believers. Where in this meal believers are spiritually nourished, acquire spiritual strength, receive the grace of God and are reconciled to God through Christ's sacrificial death on the cross. Interestingly, Michael Welker observes that there is a unique thing that happens at the Eucharist because:

Here the church of Christ is in fact built up. Here human beings experience God's vitality in peaceful, liberated community. Here the presence of God's spirit becomes available to the senses. A creative process takes place. Something happens in the Holy Communion which is difficult to grasp, but which is of elementary importance. ${ }^{50}$

In these notes, the Eucharist opens diverse realities to humanity because partakers in this meal form part of liberated community of God where they experience these unique things. However, it is conditional for the participants to encounter the mystery and unique experiences in the Eucharist as participants are required to examine their lives before partaking of this meal. While in some traditions, there is provision of personal confession of sins before the priest, in the ACK the practice is assumption that communicants will personally evaluate their life and if not right with God repent their sin and resolve to lead a new life. This being the practice in the ACK, it is believed to have been derived from the Anglican reformers such as Richard Hooker who in support of this exhort that communicants need to examine their lives and conversations

48 Thomas Aquinas (Trans. William Barden), Summa Theologie Vol. 58: The Eucharistic Presence (3a. 73-78), (London: Eyre and Spottiswoode Ltd, 1965), 109.

49 JF Bethune-Baker, An Introduction to the Early History of Christian Doctrine, 394.

50 Michael Welker, What Happens in Holy Communion? (Grand Rapid: WMB Eerdmans Publishing, 2000), 8. 
by the rule of God's commandments for otherwise the receiving of Holy Communion doth nothing else but increases your damnation. ${ }^{51}$

In spite of this inherited understanding and practice in this sacramental rite in the ACK, it is sad to note that some communicants partake of this meal without proper examination. They participate only for identification and not for spiritual conviction as indicated here that:

“... you go because you want people to see you that you are communicants ..." 52

The implication according to the diocesan Christians is as narrated here below that:

“... We are perturbed when we see 'wrong people' lining up to receive Holy Communion while you remember what they did yesterday or where they were." ${ }^{53}$

Another participants contributing to this predicament in this Eucharist perceives communicants

“... 'plunging' in the Holy Communion with 'mud'." 54

These responses indicated that communicants with questionable behaviour referred here as "wrong people" have tainted this central sacrament in the Christian life. As such respondent 03\# observed communicants with "mud" which is metaphorical expression in Kikuyu worldview imply unclean and unrepentant communicants do participate in the Eucharist. The implication or the "sin" these so called "wrong" people commit in this Eucharist, according to respondent $02 \#$ is travesty that make them disturbed when they see the "wrong" people joining others for communion. Due to this quandary at the Eucharist the diocesan Christians perceive this as change because this ecclesiastical meal instituted by Christ for the church has become fashionable to communicants leading to the decline of initial glory that used to be experienced by Communicants in their local

51 GR Evans \& J Robert Wright ed., The Anglican Tradition: A Handwork of Resources, (London: SPCK. 1991), 250.

52 Interview with Respondent 01\#, Field Notes, (Kiganjo East, 27 November 2013).

53 Interview with Respondent 02\#, Field Notes, ( Ndunyu Chege, 18 November 2013)

54 Interview with Respondent 03\#, Field Notes, (Kiganjo East, 27 November 2013). 
churches. We now turn to this change in understanding and discuss why the Eucharist has become fashionable in the diocese of Thika where this phenomenon is perceived to repudiate God's glory.

\section{The Eucharist becoming fashionable to the communicants today}

While Christ instituted the Eucharist for spiritual nourishment and strength to the believers, it is unfortunate to note that this meal has been understood otherwise in the diocese of Thika. Although we are not disqualifying the sociological perspective of religion as it is good to identify with one ecclesiastical tradition for spiritual nourishment and edification of one another, what we are unveiling in this article is that believers in the diocese of Thika are becoming communicants of the Eucharist because it is fashionable. This is evident in some diocesan Christians' responses that attest to this fact as stated:

"It is only now that people have taken Holy Communion lightly, in the past it was very significant because when it was announced that there will be Holy Communion, one was able to prepare thoroughly and when you come to church on that Sunday you saw in the church that truly there is unique thing happening. Not like today, where people go to the church as a custom because others are going, but in the early days it was very crucial." ${ }^{5}$

“... you go [to partake Holy Communion] because you want people to see you that you are communicants ..."56

In light of these responses, it is correct to suggest that the Eucharist has been linked and associated with social identity that is admired by many diocesan Christians. This means that some diocesan Christians become communicants in order to belong to a class of their own and also not to become the odd one out in the Church. This is echoed by respondent \#01 that some Christians become communicants for "people to see you that you are communicants". The result is that the "Holy Communion being

55 Interview with Respondent, Field Notes 04\#, (Gituamba, 28 November 2013).

56 Interview with Respondent, Field Notes 01\#, (Kiganjo East, 27 November 2013). 
taken lightly" as alluded by respondent $04 \#$ and "the unique thing" that used to be experienced at this meal being no longer experienced. Therefore, it is important for the Church to re-examine why in the diocese it is a prestigious thing being a communicant. This signifies that diocesan Christians are becoming communicants of the Eucharist not out of spiritual conviction but for association in their local ecclesia. Joseph Galgalo observes this phenomenon in Africa, where Christianity is for most part a religion of convenience, social identity, a way to be, and not necessarily a spiritual home and certainly not the only spiritual home for most professing Christians. ${ }^{57}$ Apparently, most communicants in Thika diocese understand the distinctive purpose of participating in this meal as a lifestyle rather than a significant meal in their spiritual life. As Michael Green in Tom Wright's book The Meal that Jesus Gave Us: Understanding Holy Communion observes, it is a reality in our Churches that many within the Church go to communion from habit but know very little about how it arose and what it means. ${ }^{58}$

\section{Waning of the initial glory of the Eucharist}

Another change in the Eucharist is the perception that the initial glory that used to be experienced in the church has declined. Some diocesan Christians were convinced that in the Eucharist a unique thing happens since the communicants encounter God and more so the mystery of his incarnation in Jesus Christ. This mystery that hovers in the Eucharist is referred by some diocesan communicants as "God's glory" and is attested by respondent $04 \#$ who maintains:

"In the past it was very significant because if it was announced that there will be Holy Communion, one was able to prepare thoroughly and when you come to Church on that Sunday you saw in the Church that truly there is unique thing happening." ${ }^{9}$

57 Joseph D Galgalo, African Christianity: The Stranger within, (Limuru: Zapf Chancery, 2012), 6 .

58 See Thomas Wright, The Meal Jesus Gave Us: Understanding Holy Communion, (Louisville: John Knox Press, 1999).

59 Interview with Respondent, Field Notes 04\#, (Gituamba, 28 November 2013). 
What is notable here is the nostalgic experience by the older generation who used to experience the "unique thing" in the Eucharist. However, it is unfortunate because they perceive things changing for worse and not for good. This is evident in the analysis of the respondent 04 \# that prompts one to link this change to preparation of the communicants in the Eucharist. As she confesses that through "thorough preparation" before the Eucharist guaranteed the unique encounter in this meal. This implies then that there is something missing in Thika diocese while preparing the candidates for confirmation and there is an urgent need to arrest this problem in the churches if this meal is to continue stirring unique things in the life of communicants again. Therefore to continue interrogating the change, we will look at the factors behind the changing trend.

\section{Factors contributing to the change of understanding in the Eucharist}

\section{Poor teaching}

Christianity is a teaching faith and this is emulated from her master Jesus Christ who was a teacher par excellence. This phenomenon was taken up by the Early Church in preparation of the communicants such that those who participated in this meal were first taught then admitted as communicants. Justin Martyr put this right by saying no one was allowed to partake who does not believe what we teach is true, and has not been washed with the laver of baptism for the remission of sins and unto regeneration. ${ }^{60}$ This ecclesiastical practice was also passed down by the missionaries when they introduced the Christian faith in Kenya as Julius Gathogo affirms by citing the CMS missionary Johannes Krapf modal of Christian teaching. ${ }^{61}$

However, there is a gap to be bridged between the missionary era and the present church in terms of teaching as the change in the Eucharist in the diocese of Thika points that the teaching is wanting. As in the

60 John Kaye, The First Apology of Justin Martyr: Addressed to the Emperor Antoninus Pius, (Edinburgh: John Grant, 1912), 65.

61 Julius Gathogo, "Historical Developments of Christian Education in East Africa: The Example of Johannes Krapf". In Handbook of Theological Education in Africa, editors Isapel Apawo Phiri and Dietrich Werner (Dorpspruit: Cluster Publications, 2013), 28 46. 
semi-structured interview thirteen out of twenty one respondents that translate into $62 \%$ cited poor teaching as factor motivating this change. This raises the concern of who is responsible for teaching in the church? In the principles of reformers on priesthood of all believers this is a corporate responsibility in the body of Christ but in the Anglican tradition it is perceived as the prerogative of the clergy. But, it is worth noting that it is overwhelming to clergy because in the Kenyan province statistics the Anglican population of about 3,711,890 Christians is served by only about 1,555 clergy, translating to clergy per Christian ratio of about 1:2400. ${ }^{62}$ These statistics imply that it is very difficult for the clergy to offer good pastoral care to their flock and this means no proper and adequate teaching is happening in the Churches because the priests are not able to reach out to the congregants and give them proper attention needed due to their population. Besides the few clergy in the congregations, poverty also escalates this problem because many congregations cannot afford ordained professional clergy due to poverty. ${ }^{63}$ The implication of this trend in the diocese of Thika and in the ACK at large is that a priest is shared among congregations. Thus, it goes without saying that catechism training is in hands of catechists who are laity and with no theological training in the diocese and Province. Since the ACK subscribes to the reformation principle of priesthood of all believers, this becomes good premises for the Church in the diocese to rethink the critical role played by the laity in the Church and begin equipping them adequately to fill the vacuum as a result of insufficient priests in the Church.

\section{Diversion from inherited Anglican practice of thorough examination before the Holy Communion}

Another factor contributing to the change is diversion from the inherited practice of thorough examination before communion in the Eucharist. In the ACK, there was the practice of informing the communicants of forthcoming Eucharist service where communicants were expected to have a week or so to examine their lives. There were words read to Christians

62 Dickson Nkonge, "Equipping Church Leaders for Mission in the Anglican Church of Kenya”, Journal of Anglican Studies 9, (September 2011), 154.

63 Jesse Mugambi, From Liberation to Reconstruction: African Christian after the Cold War, (Nairobi: East African Education Publishers, 1995), 146. 
before Eucharist in the Book of Common Prayer (Translated version of 1662 BCP into Kikuyu). On the Eucharistic Sunday when the priest invokes these words "all of you who repent of your sins, who love your neighbours and intend to lead a new life, following the way of Jesus, come with faith and take this Holy Sacrament to strengthen you." 64 These words became alive and affirming to communicants who were yearning for the body and blood of Christ, as this inherited understanding and practice was so significant in the life of the church and to communicants such that during the service "you saw in the Church that truly there is a unique thing happening" as respondent 04 \# claimed.

Sadly, this practice in the Eucharist has declined and in return the communicants are taking the Eucharist lightly and without thorough preparations as expected. This is a result of failure of the diocesan Church to adequately inculturate the inherited Anglican understanding and practice of preparing communicants, a practice that is similar to the Kikuyu religious practice of drawing nearer to Ngai [the name of God for Kikuyus] for sacrifice. Jomo Kenyatta put the Kikuyu religious practice succinctly that:

A public proclamation is made announcing the date of the ritual ceremony. A notice given in advance that after five days and nights have passed, the sixth day will be a day of communion with MweneNyaga ${ }^{65}$ and that no one will be allowed to make a journey ... to ford a river or a stream, that no stranger will be permitted to come in or depart on that day of communion. ${ }^{66}$

Though the inherited Anglican understanding and practice of preparing communicants before Communion fitted very well with Kikuyu religious worldview during the major religious activities that required communal cleansing prior sacrifices to Ngai, it is clear this has not being fully integrated in the Eucharist among the diocesan Christians. This is in spite of faith seeking understanding through culture that is the appropriate hermeneutical tool for deeper understanding. Thus, if this is done in the

64 See Anglican Church of Kenya, Our Modern Service, (Nairobi: Uzima Press, 2002).

65 This term is an attribute of God as the owner and provider of everything to humanity, thus depicts the providence of God.

66 Jomo Kenyatta, Facing Mount Kenya: The Tribal Life of the Gikuyu, (London: The Heinemann Group of Publishers, 1938), 245. 
Eucharist there is no doubt that it would become an opportunity for the diocesan Christians to encounter Ngai the Mwene-Nyaga. Therefore, the inculturation of the understanding and practice of preparing communicants before Eucharist in the diocesan context would become an opportunity for the Christians to experience God more deeply as the primary aim of inculturation is to facilitate the experience of God within and through the instrumentality of the culture. ${ }^{67}$ In this regard, inculturation of this Anglican understanding and practice of preparing communicants would translate to reverence being accorded to this Eucharist and communicants preparing thoroughly before communion. In return the glory that used to be enjoyed and experienced would prevail again.

\section{Church leadership}

Another reason cited is the wanting role of the clergy and those in leadership position in the Church. This is attested by sixteen out of twenty one respondents in the semi-structured interviews that translate into $77 \%$ of the respondents singling out leadership as a factor contributing to this change. The diocesan clergy admitted that their negligence and laxity in this meal as cited here:

"Today we prepare the table just like that. And people do not even find themselves coming in. They just come and take and I think failure of not preparing them makes them water down the aspect of that." 68

"Nowadays I can see sometimes in the past the communicants used to prepare themselves more, they were announced early enough and they used to feel that as Moses was telling the children of Israel cleanse yourself three days in time you are going before the Lord yeah that one is not almost appearing that weight nowadays." ${ }^{69}$

These responses indicated that the clergy has failed in their noble task of teaching, and in this case, in the sacrament of the Eucharist. This affirms

67 Jose de Mesa, "Inculturation as Pilgrimage". In Mission and Culture: The Louis J. Luzbetak Lectures, Stephen B. Bevans, ed., (Maryknoll, New York: Orbis Books, 2012), 6.

68 Interview with Respondent, Field Notes 05\#, (Thika Town, 26 November 2013).

69 Interview with Respondent, Field Notes 02\#, (Gituamba, 28 November 2013). 
the Kikuyu saying ciathua ndongoria itikinyagira nyeki implying that if the leadership fails and have no vision the entire group is deemed to perish. Hence Eucharist has failed to achieve fully its desired goal among the communicants resorting to travesty due to the poor leadership by the clergy in the diocese.

In light of the above, therefore, it appears that the Eucharist has been understood differently in the diocesan context of Thika. Contrary to this meal being perceived as intended for spiritual nourishment and strength, channel of conveying God's grace to the communicants and uniting them with God and one another, it has been seen as a simple social function. The missionary inculcated concept of Christians as athomi that literally meant Kikuyu mission adherents as readers where the deeper symbolic meaning of being Christians meant you are learners has been lost. ${ }^{70}$ The concept was used during the missionary era among the Kikuyu so much so that being a Christian was seen to involve continuous learning accompanied with follow-up in order to be equipped effectively. The revival and reincarnation of athomi's core values, remains the solution to the change witnessed in the Eucharist in the diocese and ACK at large. The Christian faith as teaching faith will ensure deep-rooted communicants who fully understand the significance of this meal in their Christian life. Through inculturation, faith seek understanding through people's culture in order to assume their flesh, the adoption of this concept in the life of the Church will ensure that communicants are fully taught and fully prepared before participating in the Eucharist so that they may be outstanding before God. When adequately equipped through teaching the participants will be conscious it is still healthy to abstain partaking of this meal when they have not fully examined their life the way respondent $01 \#$ states that communicants will be aware that "you would rather refrain if it means for a period of time until you feel that you are in a state of right with God." ${ }^{71}$

70 See John Karanja, Founding an African Faith: Kikuyu Anglican Christianity 1900-1945, (Nairobi: Uzima Press, 1999), 47.

71 Interview with Respondent, Field Notes 04\#, (Kiganjo East, 27 November 2013). 


\section{Conclusion}

It has been argued in this article that the Eucharist was a new experience to the Kikuyu people but with time, the meal became assimilated in the people's ways of life. Therefore, this article elucidated the deeper meaning of the Eucharist in the life of Kikuyu communicants in Thika. The missionaries emphasized that at Communion something unique happen to the communicants as there is spiritual nourishment and strength, God's grace is received and there is unity with one another and with God. However, this perception has gradually disappeared and there is dire need to re-emphasize on teaching communicants because there is a descending spiritual value in the entire administration of the Eucharist as experienced by communicants of Thika diocese. The disappearance of this "unique thing" has had a lot to do with how congregants are prepared for the meal, how the clerics teach it, as well as the expectations of the communicants. The concept of self-examination by participants as well as their perceived presence of the "unclean other," the "wrong people with mud," is seen to be interlinked with the presence of Christ in the meal. These have led to Eucharist being taken lightly in Thika diocese where the sacrament is now associated with social identity and not spiritual conviction. Hence, this article suggests the need to revive the missionary era concept of athomism in this meal as the way forward. This will ensure deeper understanding of this meal to communicants' life and also ensure proper preparation of the communicants before communion in the ACK. In return the waning glory will be restored and the Eucharist will be taken seriously as it deserves.

\section{References}

\section{Oral Interviews}

$\begin{array}{llll}\text { Interviewee } & \text { Location } & \text { Interviewer } & \text { Date } \\ \# 01 & \text { Kiganjo East } & \text { Georg Kiarie } & \text { 27 November } 2013 \\ \# 02 & \text { Ndunyu Chege } & \text { Georg Kiarie } & \text { 18 November } 2013 \\ \# 03 & \text { Kiganjo East } & \text { Georg Kiarie } & \text { 27 November } 2013 \\ \# 04 & \text { Gituamba } & \text { Georg Kiarie } & \text { 28 November } 2013 \\ \# 05 & \text { Thika Town } & \text { Georg Kiarie } & \text { 26 November } 2013\end{array}$




\section{Published works}

Anglican Church of Kenya, Church Diary and Lectionary, Nairobi: Uzima Press, 2015.

- Our Modern Service, Nairobi: Uzima Press, 2002.

Aquinas Thomas (Trans. William Barden), Summa Theologie Vol. 58: The Eucharistic Presence (3a. 73-78), London: Eyre and Spottiswoode Ltd, 1965.

Bethune-Baker, JF. An Introduction to the Early History of Christian

Doctrine: To the Time of the Council of Chalcedon. London: Methuen \& Co., 1903.

Boyatzis, Richard E. Transforming Qualitative Information: Thematic Analysis and Code Development, Thousand Oaks, CA: SAGE Publications, Inc., 1998.

Cocksworth, Christopher John. "Eucharistic Theology". In The Identity of Anglican Worship, edited by Kenneth E. Stevenson and Bryan D Spinks, 49-68. London: Mowbray, 1991.

Cox, John Edmund (ed.), Works of Archbishop Cranmer on the Lord's Supper, Cambridge: Cambridge the

Cranmer, Thomas. Cranmer on the Lord's Supper: A Defence of the True and Catholic Doctrine of Sacrament, Kent: Focused Christian Ministries and Harrison Trust, 1987.

Creswell, John W and Vicki L. Plano Clark, Designing and Conducting Mixed Methods Research, Thousand Oaks: SAGE Publications, Inc., 2007.

Crocket, William R. Eucharist: Symbol of Transformation, New York: Pueblo Publishing Company, 1989.

de Mesa, Jose "Inculturation as Pilgrimage". In Mission and Culture:

The Louis J. Luzbetak Lectures, edited by Stephen B. Bevans, 5-34. Maryknoll, New York: Orbis Books, 2012.

Dearmer, Paul. 1917. The Parson's Handbook Ninth edition. London: Humphrey Milford. 
Douglas, Brian. A Companion to Anglican Eucharistic Theology Vol. 2: The 20th Century to the Present, Leiden: Brill, 2012.

Dowley, Tim (ed.). 1990. The History of Christianity. Oxford: Lion Publishing Plc.

Evans G. R and J. Robert Wright (ed.), The Anglican Tradition: A Handwork of Resources, London: SPCK. 1991.

Galgalo, Joseph D. African Christianity: The Stranger within, Limuru: Zapf Chancery, 2012.

Gathogo, Julius. "Historical Developments of Christian Education in East Africa: The Example of Johannes Krapf". In Handbook of Theological Education in Africa, edited by Isapel Apawo Phiri and Dietrich Werner 28-46. Dorpspruit: Cluster Publications, 2013.

Githiga, Gideon. Effective Church Leadership, Nairobi: Uzima Press, 2009. Hague, Dyson. 1932. Through the Prayer Book. London: Longmans Green \& Co.

Howe, John W and Pascoe, Sam C. 2010. Our Anglican Heritage: Can an Ancient Church be a Church. Eugene OR: Wipf and Stock Publishers. Karanja, John. Founding an African Faith: Kikuyu Anglican Christianity 1900-1945, Nairobi: Uzima Press, 1999.

Kaye, John. The First Apology of Justin Martyr: Addressed to the Emperor Antoninus Pius, Edinburgh: John Grant, 1912.

Kenyatta, Jomo. Facing Mount Kenya: The Tribal Life of the Gikuyu, London: The Heinemann Group of Publishers, 1938.

Lampe, GWH. Doctrine in the Church of England, London: SPCK, 1982. Macquarrie, John. A Guide to the Sacraments, London: SCM Press, 1997. Magesa, Laurenti. Anatomy of Inculturation: Transforming the Church in Africa, Maryknoll: Orbis Books, 2004.

Mashall, Howard I. Last Supper and Lord's Supper, Exeter: The Paternoster Press, 1980. 
Mbiti, John S. New Testament Eschatology in an African Background: A Story of the Encounter between New Testament Theology and African Tradition Concepts, London: SPCK, 1971.

McGrath, Alister E Christian Theology: An Introduction, Oxford: Blackwell, 2001.

Meyer, CS. Cranmer's Selected Writings, London: SPCK, 1961.

Meyer, Ruth A. 1994. "The Common Cup and Common Loaf”. In Revising the Eucharist, edited by David R. Holeton, Nottingham: Grove Books Ltd. Pp. 45-47.

Moor, Janny De. 1994. "Wafers and its Roots," Pages 119-127. In Look and Feel: Studies in Texture, Appearance and Incidental Characteristics of Food Proceeding of the Oxford Symposium on Food and Cookery, edited by Harlan Walker, Oxford: Prospect Books.

Moreton, Michael. “The Language of Christian Mystery of Redemption”. In Signs of Faith, Hope and Love: The Christian Sacraments Today, edited by John Greenhalgh and Elizabeth Russell, 45-56. London: St Mary's Bourne Street, 1987.

Mugambi, Jesse. African Heritage and Contemporary Christianity, Nairobi: Longman Kenya Limited, 1989.

Mugambi, Jesse. From Liberation to Reconstruction: African Christian after the Cold War, Nairobi: East African Education Publishers, 1995.

Neil, Stephen. "Holy Communion in the Anglican Church". In The Holy Communion, edited by Martin Hugh. 49-66. London: SCM Press Ltd, 1947.

Nkonge, Dickson. "Equipping Church Leaders for Mission in the Anglican Church of Kenya", Journal of Anglican Studies 9, (September 2011): 154-174.

Okullu, Henry. Church and Politics in East Africa, Nairobi: Uzima Press, 1974. University Press, MDCCCXLIV.

Uzukwu, Eugene. 1980. "Foods and Drink in Africa and the Christian Eucharist”, African Ecclesial Review, 22/6,370-385. 
Von Allmen, Jean-Jacques. 1969. The Lord's Supper. London: Lutherworth Press.

Wanyoike, Mary M. Wangu wa Makeri, Nairobi: East African Educational Publishers Ltd, 2002.

Welchman. The Thirty-Nine Articles of the Church of England, London: Oxford Theatre, MDCCLVII.

Welker, Michael. What Happens in Holy Communion? Grand Rapid: WMB Eerdmans Publishing, 2000.

Wright, Thomas. The Meal Jesus Gave Us: Understanding Holy Communion, Louisville: John Knox Press, 1999. 